https://doi.org/10.15407/scin16.02.079

SEMYKIN, S.I., GOLUB, T.S., and DUDCHENKO, S.A. Iron and Steel Institute of Z.I. Nekrasov, the NAS of Ukraine, 1, Ac. Starodubov Sq., Dnipro, 49107, Ukraine, +380 56790 0512, office.isi@nas.gov.ua

\title{
IMPROVING THE EFFICIENCY OF THE LOW-VOLTAGE POTENTIAL APPLICATION METHOD AT TOP OXYGEN BLOWING IN CONVERTER
}

Introduction. The main factor of oxygen blowing in converters is the interaction of oxygen jet with the molten metal bath. It determines hydrodynamics, heat and mass transfer, slag formation and causes metal losses with emissions affecting the yield of liquid steel.

Problem Statement. The most promising research aimed at improving the slag formation and increasing the yield of liquid steel in the conditions of modern metallurgical practice. It deals with the electro physical effects on the metal smelting process. It includes the method of low-voltage potentials application developed in the Iron and Steel Institute of Z.I. Nekrasov of the NAS of Ukraine (ISI NASU).

Purpose. To study the possibilities and to evaluate ways to improve the efficiency of the method of low-voltage potential application for top oxygen blowing in the converter.

Materials and Methods. The tests were carried out on a 160-ton industrial oxygen converter equipped with a device for low-voltage potential application on the lance and a metal bath with imposition of a negative or positive polarity to the lance throughout the blowing period. The top blowing option through five nozzle tip has been studied while producing medium carbon steel with intermediate deslagging.

Results. The analysis of the array of experimental industrial heats carried out in 160-t converters in conditions of low-voltage potential application, has made it possible to identify the following patterns of changes in the electrical characteristics of the bath from the blowing parameters. It was established that regardless of the polarity of the potential at the lance, the magnitude of the values of current and useful power of impact in lance-metal bath circuit over blowing periods depends on: the level of the voltage at the source of current and the height of the lance in the converter's volume above the metal bath. Thus, it is necessary to maintain the position of the lance: from the beginning of the blowing, depending on the location of the scrap, at a height of 0.9-1.0 m, in the main blowing period, at 1.0-1.2 $\mathrm{m}$, and in the final period, at 1.0-1.1 m, which is made taking into account the effective support of the current during the blowing at an adequate level to achieve the maximum level of the effect of the low voltage potential application.

Conclusions. Industrial testing of the recommended blow mode in 160-t converters showed the possibility to almost double the efficiency of using low-voltage potential application compared with the previously developed and accepted at the plant mode of its application.

Keywords: oxygen converting, low-voltage potential, current strength, useful power, lance position.

Цитування: Semykin, S.I., Golub, T.S., and Dudchenko, S.A. Improving the Efficiency of the Low-Voltage Potential Application Method at Top Oxygen Blowing in Converter. Nauka innov. 2020. V. 16, no. 2. P. 7986. https://doi.org/10.15407/scin16.02.079 


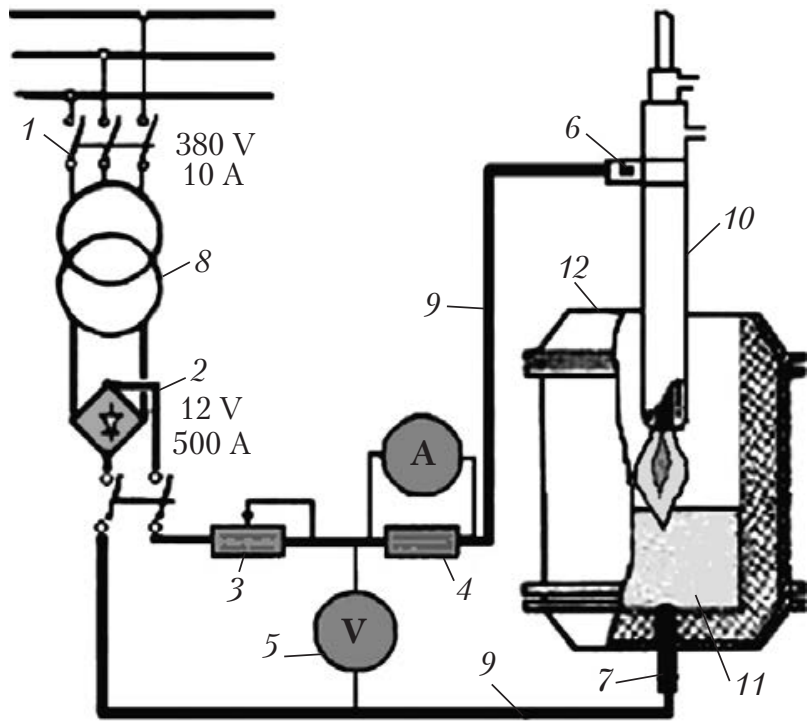

Fig. 1. Schematic diagram of the experimental set-up: $1-$ starter; 2 - rectifier; 3 - resistance; 4 - shunt and ammeter; 5 - voltmeter; 6 - current supply to the lance; 7 - bottom contact electrode-carbon contained refractory brick; $8-$ source of current; 9 - copper cables; 10 - lance; 11 - metalslag bath; 12 - converter

According to Worldsteel, in 2018, the world crude steel production reached 1808 million tons [1]. At the same time, almost 21 million ton steel is produced in Ukraine. Due to its "flexibility" and fast adaptability to changing charge and technological conditions, the oxygen converter process has the major share in it.

The main factor of oxygen blowing in converters is the interaction of high-speed oxygen jet with the molten metal bath [2-6]. It determines hydrodynamics, heat and mass transfer, slag formation and cause the amount of metal losses with emissions affecting the yield of liquid steel [7$10]$. The most promising research aimed slag formation improvement and yield of liquid steel increase in the conditions of modern metallurgical practice include electro physical effects on the process of metal smelting, that include the method of low-voltage potentials application developed in the Iron and Steel Institute of Z.I. Nekrasov of the NAS of Ukraine (ISI NASU). The method utilized a low voltage application to the slag-metal steelmaking bath and improves heat and mass transfer in the top blown oxygen converter. Numerous industrial trials confirmed the advantages of the suggested method: increasing the metal temperature (on average by $8-12{ }^{\circ} \mathrm{C}$ ), decreasing consumptions of pig iron and metal charge (by $3-8 \mathrm{~kg} / \mathrm{t}$ ), increasing the refining degree of metals, and some others [11].

The purpose of this work was to study and evaluate the possibilities to improve the efficiency of the method of low-voltage potential application for top oxygen blowing in the converter.

The industrial trials were performed with an 160-t top blown oxygen converter (working volume $125 \mathrm{~m}^{3}$ and metal level $1.3 \mathrm{~m}$ ) specially equipped for the low voltage application of positive or negative polarity to the electrically isolated lance and opposite polarity to the bottom electrode made of carbon-containing refractories during the whole blowing period. In these tests, a five-nozzle top lance with a critical section diameter of Laval nozzle of $32 \mathrm{~mm}$ and the angle of inclination of the nozzle to the lance axis of 14 degrees was used. The oxygen was blown for 20-22 min at $380-420 \mathrm{~m}^{3} / \mathrm{min}$. Schematic diagram of the experimental set-up is given in Fig. 1.

The heats were carried out at medium-carbon steel smelting according to the technology with intermediate deslagging on the options: 1 - without effects; 2 - with a supply to the lance of a potential of negative polarity; 3 - with a supply of positive polarity. During the blowing the lance position and electrical characteristics for the circuit lance-metal bath for options 2 and 3 (current and voltage) were recorded on a PC.

Blowing mode was characterized with a small amount of slag at a practically unchanged position of the lance during the smelting. The technological modes of smelting in the oxygen converters were regulated by "The technological instruction" of the enterprise.

Figs. $2-3$ show the diagrams of change of the lance height and electrical parameters in the lance-metal bath circuit (current and voltage) during the heats with low-voltage application of different polarity on the lance. 
Fig. 2. Diagrams of change of the current $(a)$, voltage $(b)$ measured in a circuit a blowing lance-metal bath at a certain lance position above the metal $(c)$ at low-voltage application of negative polarity on the lance

Fig. 3. Diagrams of change of the current $(a)$, voltage $(b)$ measured in a circuit a blowing lance-metal bath at a certain lance position above the metal $(c)$ at low-voltage application of positive polarity on the lance
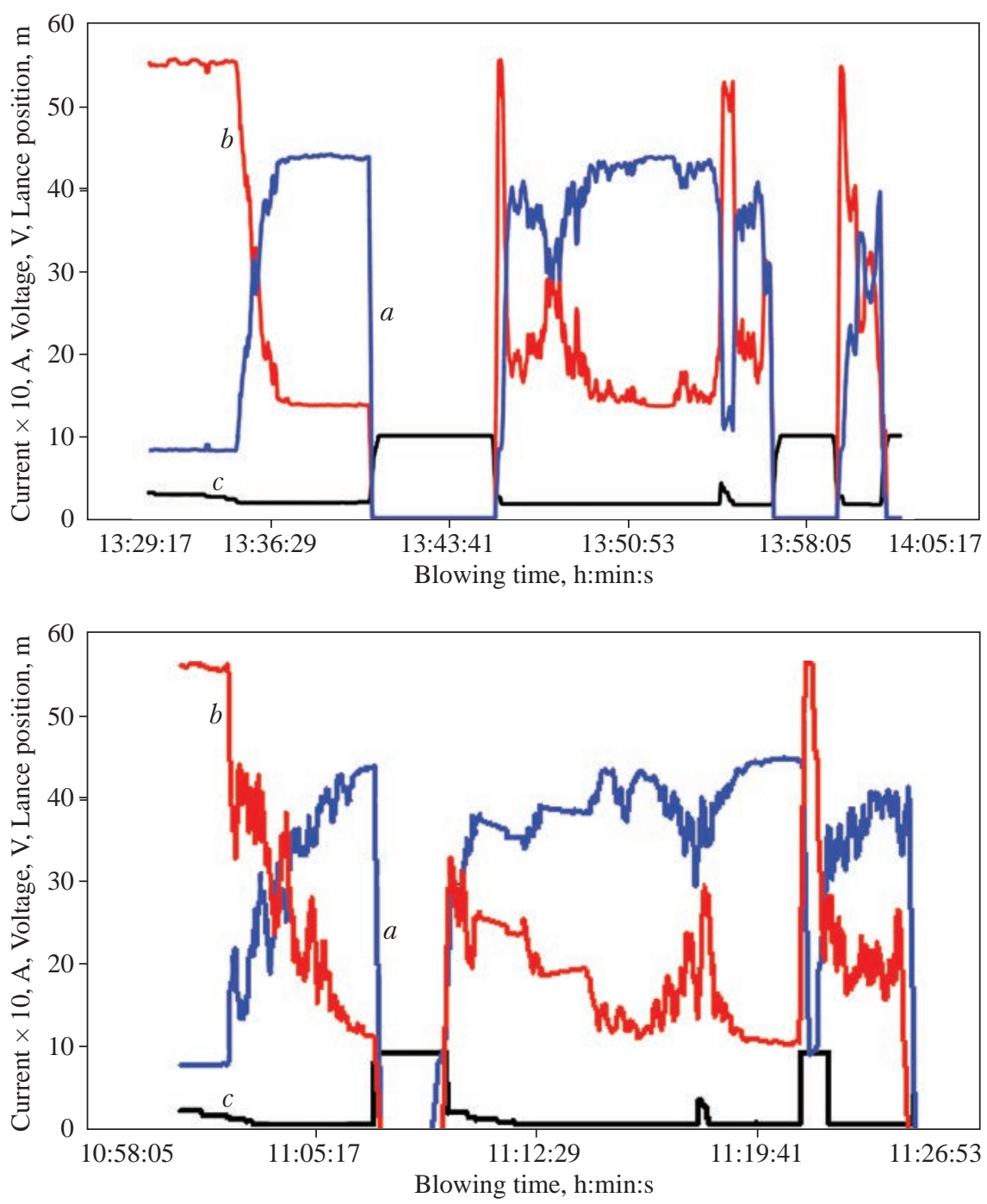

It was established that the dynamics of changes in the electrical properties of the bath was variable during the blowing and differs somewhat depending on the polarity of the potential: the level of current at negative polarity of potential on the lance was higher than at positive polarity of potential even despite the unchanged level of the lance position for a long time during the blowing.

It follows from the diagrams that option 2 was characterized by a smoother increase in current values to maximum values at the beginning of the blowing till the deslagging without significant fluctuations. It corresponded to uniform active slag formation in this option with bath foaming and ensuring even and constant contact in the lance-metal bath circuit that corresponds to the results of previous studies [12-13]. Option 3 was characterized by an abrupt increase in current (amplitude of 5-10 A) in the period before deslagging. It probably indicates less favorable conditions for slag formation from the point of view of ensuring contact in the lance-metal bath circuit for low-voltage potential application. However, values of current close to those obtained in option 2 were achieved.

Analysis of diagrams of current and voltage changes indicates similar changes in time of the 


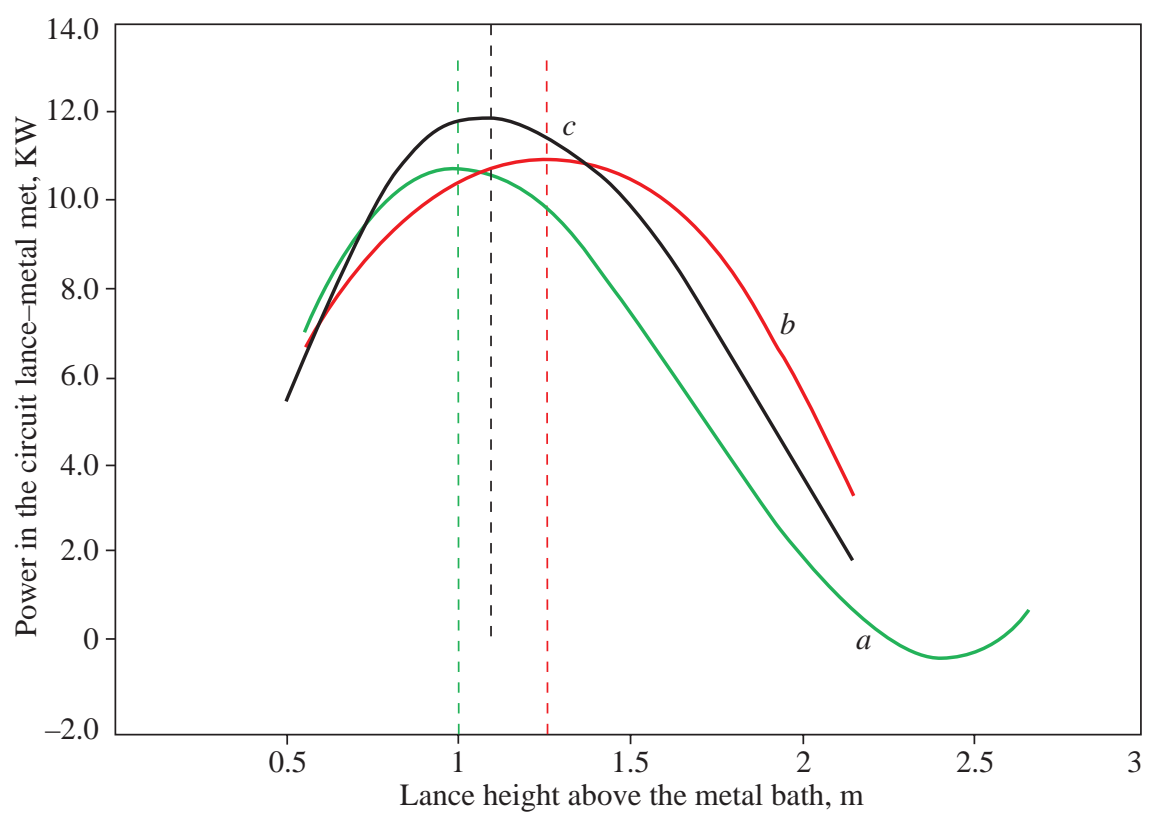

Fig. 4. Dependence of power in lance-metal bath circuit from the height of the lance in blowing periods: $a$ - before deslagging; $b-$ main blowing period, $c$ - final blowing period at the beginning of the lining campaign values repeated from melting to melting, and reflecting, first of all, the mutual arrangement of the lance and the metal bath by blowing periods. High values of voltage correspond to low values of current in the circuit and vice versa. Lowering the lance position into the converter or raising the level of the bath was accompanied by a decrease in the voltage and an increase in the current values.

In general, the analysis of the graphs of current change over time, obtained under the operating conditions of industrial converters, showed the following. The initial blowing period was characterized by a minimum level of current that was a consequence of both a small amount of slag and its poor conductivity. The first maximum in the metal bath conductivity was at the end of the process of oxidation of silicon - the period before deslagging. By this period, the slag basicity usually approached 1.5 units that lead to its significant foaming. After the deslagging, a high level of current was observed at the beginning of the second blowing period. It reflects the guidance of ferrous slag, since silicon has already burned out, and the reaction of carbon oxidation was not yet sufficiently developed. The second rise in the values of the magnitude of the current was in the middle of the blowing. It was associated with a significant intensification of the process of carbon oxidation. During this period, the bath was boiling that increased the level of current due to increase the contact area of the lance with a slag-metal emulsion. During this period, the operator raised the lance position to maintain the oxidizing potential of the slag. Further, the carbon content in the metal reached $0.7-0.8 \%$ and there was a transition from surface to bulk oxidation of carbon with the accumulation of oxygen in the metal and the intensity of the carbon oxidation process increases [14-15]. In this period the level of slag-metal bath and the contact in the lance-metal bath chain were also reduced. Further when the carbon amount in the metal decreases lower than $0.2-$ $0.3 \%$ the level of iron oxides in the slag increases and the slag-metal bath rise up again. It cause increase the current in the lance-metal bath circuit. Respectively, the values of the current during the blowing are largely determined by both the position of the lance and the state of the slag phase.

It was experimentally established that the option with a negative polarity of potential on the lance was characterized by higher values of the "useful" power than the option with a positive 
polarity of potential on the lance. The reason probably is the characterized for negative polarity of potential active slag formation that is accompanied by an active bath foaming [12-13]. It provides an increase in the contact surface of the lance with a slag-metal bath and consequently contributes to an increase in the magnitude of the impact power.

Special analysis of dependence of power in lance-metal bath circuit from the height of the lance position for different periods of blowing: before deslagging, the main part of blowing, the final part of blowing for two periods of converter operation: at the beginning of the campaign on the lining and at the end of the lining campaign showed the following (as an example diagrams of dependence of circuit lance-metal bath power on the lance position above the metal bath at the beginning of the lining campaign are shown in Fig. 4). The lance begins to interact with the slag melt when the height of its location decreases to the level of $2.0-2.5 \mathrm{~m}$. Then the maximum power values in the initial blowing period correspond to the lance height about $0.9-1.0 \mathrm{~m}$. In the main part of the blowing, the maximum power was reached at the position of the lance of about 1.0$1.2 \mathrm{~m}$. At the end of the blowing the level of the lance that provided maximum power corresponded to approximately $1.0-1.1 \mathrm{~m}$. Wherein at the end of the lining campaign, the maximum power values were achieved at lower lance height than in the initial period of lining campaign due to the fact that during the campaign the lining is "worn out" and "washed out", and geometrical parameters of the bath change- it becomes lower.

Thus, it was found that to ensure the effects from low voltage potential application at the maximum level, it is necessary to provide constant best conditions for contact in the circuit of the lance-metal bath, that are characterized by the magnitude of the current (desirable with a small amplitude of values fluctuations). To provide it, it is necessary to move the lance to achieve immersion of the tip in the slag-metal emulsion layer. When the lance is located below rational level, the tip approaches the low-resistance metal melt layers that could cause the short-circuited mode. It characterizes by very low values of the voltage with the maximum values of the current determined by the power of the electrical equipment. This mode, in addition, overheats an equipment and eliminates the receipt of technological effects from low-voltage application. The rise of the lance above the rational level leads to a sharp increase in resistance at the site the lance-metal bath due to the higher resistance of the slag phase and the oscillatory movement of the reacting phases. It leads to an unstable and underrepresented mode of electrical energy transfer to the converter bath with a decrease in the current values.

Taking it into account a blowing mode was proposed and tested. It provides the low-voltage potential application during the oxygen blowing of converter bath with a negative polarity on the lance and during the blowing, after gradual lowering of the lance into the converter for the period of scrap melting, by lance moving in the converter volume relative to the reference heights (in the period before deslagging 30-32 caliber, during the main blowing of $37-40$ calibers, in the last quar-

Table 1. Recommended Parameters of the Lance Position Depending on the Current in the Lance - Metal Bath Circuit

\begin{tabular}{|c|c|c|}
\hline \multicolumn{3}{|c|}{ Blowing parameters } \\
\hline $\begin{array}{c}\text { Oxygen } \\
\text { consumption, } \\
\mathrm{m}^{3} / \mathrm{t}\end{array}$ & $\begin{array}{c}\text { Lance } \\
\text { position, } \\
\text { caliber }\end{array}$ & Current parameters \\
\hline $10-15$ & $30-35$ & Before the current in the circuit \\
\hline $15-20$ & $35-40$ & $\begin{array}{l}\text { Up to } 90-95 \% \text { of maximum cur- } \\
\text { rent level }\end{array}$ \\
\hline $25-30$ & $30-35$ & $\begin{array}{l}\text { Maintaining at the level of } 90- \\
95 \% \text { of maximum current level }\end{array}$ \\
\hline $30-35$ & $35-45$ & $\begin{array}{l}\text { Maintaining at the level of } 70- \\
75 \% \text { of the maximum current level }\end{array}$ \\
\hline $35-40$ & $30-35$ & $\begin{array}{l}\text { Maintaining at the level of } 90- \\
95 \% \text { of maximum current level }\end{array}$ \\
\hline $40-45$ & $40-45$ & $\begin{array}{l}\text { Maintaining at the level of } 70- \\
75 \% \text { of the maximum current level }\end{array}$ \\
\hline $45-50(55)^{*}$ & $30-35$ & $\begin{array}{l}\text { To maintain a steady flow of cur- } \\
\text { rent due to slag subsidence }\end{array}$ \\
\hline
\end{tabular}


Table 2. Evaluation Results of the Effectiveness of the Developed Blowing Mode in 160-t Converter

\begin{tabular}{|c|c|c|c|}
\hline \multirow[b]{2}{*}{$\begin{array}{c}\text { Blowing } \\
\text { parameters }\end{array}$} & \multicolumn{3}{|c|}{ Blowing options } \\
\hline & $\begin{array}{l}\text { Without } \\
\text { effects }\end{array}$ & $\begin{array}{l}\text { Low-voltage } \\
\text { application } \\
\text { mode, adopted } \\
\text { in the } \\
\text { workshop }\end{array}$ & $\begin{array}{l}\text { Recommended } \\
\text { blowing mode } \\
\text { with low- } \\
\text { voltage potential } \\
\text { application }\end{array}$ \\
\hline $\begin{array}{l}\text { Heat amount, } \\
\text { pierces }\end{array}$ & 70 & 70 & 70 \\
\hline Hot metal, t & 129.38 & 128.09 & 128.16 \\
\hline Scrap, t & 39.34 & 40.73 & 40.62 \\
\hline Metal charge, $\mathrm{t}$ & 168.72 & 168.82 & 168.78 \\
\hline $\begin{array}{l}\text { Unit consump- } \\
\text { tion, } \mathrm{kg} / \mathrm{t} \text { : }\end{array}$ & & & \\
\hline hot metal & 856.82 & 845.47 & 844.25 \\
\hline scrap & 260.53 & 268.87 & 267.60 \\
\hline metal charge & 1117.35 & $\begin{array}{l}1114.35 \\
(-3.0)^{*}\end{array}$ & $1111.85(-5.5)$ \\
\hline Steel, t & 151.0 & 151.5 & 151.8 \\
\hline $\begin{array}{l}\text { Liquid metal } \\
\text { yield, \% }\end{array}$ & 89.49 & $89.73(0.24)$ & $89.94(0.45)$ \\
\hline $\begin{array}{l}\text { Electric energy } \\
\text { consumption, } \\
\mathrm{W} \times \mathrm{h} / \mathrm{t}\end{array}$ & 0 & 40 & 40 \\
\hline
\end{tabular}

Note. ${ }^{*}$ Deviation from the option without effects

ter of blowing time of $32-35$ caliber), the maximum level of impact power in the lance-metal melt circuit is provided by maintaining a rational combination of the level of voltage and current in the circuit within the established limits (Table 1).

According to the developed rational blowing mode, 70 heats were carried out in 160 -t converter operation conditions (Table 2). It was noted that the melting carried out according to the recommended blowing mode with low-voltage potential application and with changing the lance height was characterized by early slag formation and maintaining slag in the foamed state without overflows and without "drying" the slag during the entire blowing. The obtained on such heats results were compared both with the mode of low-voltage potential application adopted in the workshop and with the standard option of metal blowing without electrical effects (Table 2).
The analysis of the results has shown that in addition to the previously created method of lowvoltage potential application, the recommended blowing mode enables reducing the specific consumption of metal charge by $2.5-3.0 \mathrm{~kg} / \mathrm{t}$ which is equivalent to an increase in the yield of liquid steel by $0.21-0.3 \%$. Thus, the developed and recommended blowing mode makes it possible to almost double the efficiency of using low-voltage potential application. Moreover, the number of addition blowing for every 10 heats of each option was reduced from 0.4 for the option without effects to 0.15 for the option with application of low-voltage potential under the recommended mode.

The article presents the results of industrial studies on 160-t converters the possibilities and evaluation ways to improve the efficiency of the method of low-voltage potential application for top oxygen blowing in the converter. It was found a change in the values of the electric current in the chain of a lance-metal bath reflects the state of the metal bath and is a function of a number of parameters, such as: the electrical properties of the metal bath, the space between the tip of the lance and the liquid metal bath and the dynamics of the interacting phases (gas, slag and metal), and, above all, its main component, slag metal emulsion. Lowering the lance position into the converter or raising the level of the bath was accompanied by a decrease in the voltage and an increase in the current values. High values of voltage correspond to low values of current in the circuit and vice versa.

It was established that at negative polarity of potential on the lance the higher level of useful power was observed. The second most powerful parameter that determines the magnitude of the developed electric current and power in lancemetal bath circuit is the lance position height above the metal bath in the working volume of the converter. The best work conditions for lowvoltage application in the initial period are at lance position of $0.9-1.0 \mathrm{~m}$, in the main period of blowing of 1.0-1.2 m, and in the final period 
1.0-1.1 $\mathrm{m}$, depending on the geometry of the bath (its depth during the lining campaign).

It was found that to ensure the effects from low voltage potential application at the maximum level, it is necessary to provide constant best conditions for contact in the circuit of the lance-metal bath, that are characterized by the magnitude of the current (desirable with a small amplitude of values fluctuations). To provide it, it is necessary to move the lance to achieve immersion of the tip in the slag-metal emulsion layer depending on the current change in the circuit the lance-metal bath.

Industrial testing of the recommended blowing mode in 160-ton converters, compared with the method of using low-voltage potential application adopted in the workshop, showed the possibility of an additional reduction of the specific amount of the charge by $2.5-3.0 \mathrm{~kg} / \mathrm{t}$, that corresponds to an additional increase in the liquid steel yield of $0.21-0.30 \%$ as compared to the classical converter melting option without effects.

Acknowledgments. The authors are grateful to V.V. Vakulchuk, ISI NASU researcher, and V.I. Makarenko, Head of the Converter Shop, for their valuable contribution to the laboratory and industrial experiments.

The authors declare that they have no conflict of interest.

\section{REFERENCES}

1. December 2018 crude steel production date- 64 countries reporting to worldsteel. URL: http:// www.worldsteel.org. (Last accessed: 19.12.2019).

2. Bojchenko, B. M., Ohotskij, V. B., Harlashin, P. S. (2006). Converter steel production. Dnepropetrovsk: «Dnepro-VAL» [in Russian].

3. Barker, K. J., Paules, J. R., Rymarchyk, N. (1998). Chapter 8. Oxygen Steelmaking Furnace Mechanical Description and Maintenance Considerations. Pittsburgh. The AISE Steel Foundation.

4. Bigeev, A. M., Bigeev V. A. (2000). Steel metallurgy. Theory and technology of steel smelting. Magnotigorsk: MSTU [in Russian].

5. Stubbles, J. (2005). The Basic Oxygen Steelmaking (BOS) Process. Nupro Corporation.

6. Smil, V. (2006). Transforming the Twentieth Century. Technical Innovations and Their Consequences. Oxford University Press.

7. Kolpakov, S. V., Teder, L. K., Dubrovskij, S. A. (1981). Converter smelting. Moscow: Metallurgiia [in Russian].

8. Boom, R. (2003). Mastering the heat in the Fe-C-O converter: Evolution of process control in fifty years of oxygen steelmaking. Proceedings of $4^{\text {th }}$ European Oxygen Steelmaking Conf. Austria. 12-15 may Eisenh tte sterreich, 19-37.

9. Maia, B. T., Imagawa, R. K., Petrucelli, A. C., Tavares, R. P. (2014). Effect of blow parameters in the jet penetration by physical model of BOF converter. Journal of Materials Research and Technology, 3(3), 244-256.

10. Ohnuki, K., Hraoka, T., Inoue, T., Umezawa, K., Matsumoto, N. (1994). Development of steel scrap melting process. Nippon steel technical report, $61,52-57$.

11. Semykin, S. I., Polyakov, V. F. (2014). Application of low voltages in the converter smelting of steel. Steel in Translation, 44(9), 660-664.

12. Semykina, T. S., Semykin, S. I. (2008). The effect of the polarity of the electric potential imposed on the converter bath on the state and chemical composition of the slag melt. Fundamental and practical problems of ferrous metallurgy, 15, 125-129 [in Russian].

13. Semykin, S. I., Golub, T. S. (2018). In Situ Investigation of Slag-Metal Interactions in Top Blown Oxygen Converter upon Low-Voltage Application. Journal of The Minerals, Metals \& Materials Society, 70(10), 2262-2269.

14. Luhtura, F. I. (2012). On the critical concentration of carbon in the melt in converter. Bulletin of the Azov State Technical University. Engineering sciences, 24, 49-56 [in Russian].

15. Sushenko, A. V. (2003). Determination of the critical concentration of carbon in the top blowing oxygen converter. Bulletin of the Azov State Technical University. Engineering science, 13, 1-7 [in Russian].

Стаття надійшла до редакціi / Received 10.04.19

Статтю прорецензовано / Revised 21.05.19

Статтю підписано до друку / Accepted 24.06.19 
С.І. Семикін, Т.С. Голуб, С.О. Дудиенко

Інститут чорної металургії ім. 3.І. Некрасова НАН України, пл. акад. Стародубова, 1, Дніпро, 49107, Україна,

+380 56790 0512, office.isi@nas.gov.ua

\section{ПІДВИЩЕННЯ ЕФЕКТИВНОСТІ МЕТОДУ \\ ВИКОРИСТАННЯ НИЗЬКОВОЛЬТНИХ ПОТЕНЦІАЛІВ ПРИ ВЕРХНІЙ КИСНЕВІЙ ПРОДУВЦІ КОНВЕРТЕРА}

Вступ. Основним фактором продувки в кисневих конвертерах є взаємодія кисневого струменя з розплавленою ванною, який і визначає гідродинаміку, тепло- і масообмін, шлакоутворення, а також величину втрат металу з виносами і викидами, що впливають на вихід рідкої сталі.

Проблематика. До найбільш перспективних досліджень, спрямованих на поліпшення процесу шлакоутворення й підвищення виходу рідкої сталі в умовах сучасної металургійної практики можна віднести електрофізичні впливи на процес виплавки металу, такі як метод використання низьковольтних потенціалів, що розробляється в Інституті чорної металургії ім. 3.І. Некрасова Національної академії наук України (ІЧМ НАНУ).

Мета. Дослідження можливостей і оцінка шляхів підвищення ефективності використання методу накладення низьковольтного потенціалу при верхній кисневій продувці в конвертері.

Матеріали й методи. Випробування проводили на промисловому кисневому конвертері потужністю 160 т, обладнаному пристроєм накладання низьковольтного потенціалу на фурму та металеву ванну з підведенням до фурми негативної чи позитивної полярності протягом усього періоду продувки. Було досліджено варіант продувки зверху через п'ятисоплову фурму при виробництві середньовуглецевої марки сталі за технологією з проміжним скачуванням шлаку.

Результати. Аналіз масиву дослідних промислових плавок, проведених в 160-тонних конвертерах в умовах накладання низьковольтного потенціалу, дозволив виявити закономірності зміни електричних характеристик ванни від параметрів продувки. Встановлено, що, незалежно від роду й полярності потенціалу на фурмі, величина сили струму та корисної потужності впливу у ланцюзі фурма-металева ванна за періодами продувки залежать: від напруги на джерелі струму та від взаємної висоти розміщення фурми в конвертері відносно металу. Таким чином, необхідною $€$ підтримка положення фурми: з початку продувки залежно від розміщення скрапу, на висоті 0,9-1,0 м, в основний період продувки - на висоті 1,0-1,2 м, і в заключний період $-1,0-1,1$ м, що реалізується з урахуванням ефективної підтримки сили струму під час продувки на достатньому рівні для досягнення максимального рівня ефекту від впливу низьковольтного потенціалу.

Висновки. Промислові випробування рекомендованого режиму продувки в умовах 160-тонного конвертера показали можливість майже подвоїти ефективність методу накладання низьковольтного потенціалу порівняно з розробленим раніше та прийнятим на заводі режимом його застосування.

Ключові слова: кисневе конвертування, низьковольтний потенціал, сила струму, корисна потужність, положення фурми. 